\title{
APAKAH TATA KELOLA PEREKONOMIAN DAERAH DI INDONESIA TELAH MENINGKAT?!
}

\author{
Haryo Kuncoro
}

\begin{abstract}
Governance has gone through radical changes over the last twenty five years. Seemingly, it became one of the important strategies, processes, methods and mechanisms in governing countries to achieve economic development goals. The objective of this paper is to observe the local economic governance dynamics in the case of districts/municipalities in Indonesia. First, the dynamics behavior of local governance over time is analyzed by visual inspection of their non-parametric density distribution. More deeply, we use Markov chains to predict a pattern of change in local economic governance toward its steady state. Based on comparison between 2007 and 2011 data delivered by Commission of Regional Autonomy Implementation Watch, we conclude that there is a high level of persistence in the relative position of local governance index, consistent with a low degree of mobility in the index distribution implying the implementation of governance in the districts/municipalities in Indonesia is weak enough. This finding implies that the local economic governance is a key to achieve sustainable regional economic growth in line with fiscal decentralization and regional autonomy.
\end{abstract}

Keywords: Local Economic Governance, Decentralization, Regional Economic Growth, Kernel Densities, Markov Chains

JEL Classification: H70, 043, 056

1 Lecturer at Economic Department, State University of Jakarta; har_kun@feunj.ac.id. Author would like to thank a unanimous BEMP reviewer for his/her constructive comments. Earlier version of this paper has been presented in the 11th Indonesian Regional Science Association (IRSA) Conference held by Faculty of Economics, Lambung Mangkurat University on July, 9-10, 2012 in Banjarmasin, South Kalimantan, Indonesia. My acknowledgement also goes to all participants for invaluable suggestions. However, any error, shortcoming, and confusion which may remain are my responsibility. 


\section{PENDAHULUAN}

Pada dasarnya, pembangunan daerah merupakan bagian yang terintegrasi dengan pembangunan nasional. Pembangunan daerah diarahkan untuk mencapai target nasional yang disesuaikan dengan potensi, aspirasi, dan masalah pembangunan di daerah. Maka dari itu, upaya terwujudnya pembangunan nasional merupakan tanggung jawab bersama pemerintah pusat, provinsi, dan kabupaten/kota sehingga pembangunan nasional merupakan satu kesatuan yang saling bersinergi antar kinerja pembangunan daerah (Hariyoga, 2009)

Dengan kerangka di atas, Pemerintah Republik Indonesia telah melakasanakan kebijakan desentralisasi fiskal dan otonomi daerah sejak tahun 2001. Kebijakan tersebut berdasarkan fakta bahwa wilayah seluas Indonesia dengan setiap daerah yang ada di dalamnya memiliki kondisi dan potensi ekonomi tertentu yang sangat bervariasi. Dengan kebijakan desentralisasi fiskal dan otonomi daerah, daerah-daerah tersebut diharapkan mampu untuk mengembangkan potensi ekonominya dengan lebih efektif dan efisien (Kuncoro, 2005).

Dalam perspektif makroekonomi, potensi ekonomi daerah merupakan elemen yang sangat penting untuk meningkatkan kualitas pertumbuhan ekonomi nasional. Intinya adalah, potensi ekonomi daerah melibatkan pendekatan daerah dan menyeluruh, yang menjadi koreksi bagi pendekatan industrial yang telah digunakan oleh rezim sebelumnya. Sebagai tambahan, sebagian besar pelaku ekonomi adalah usaha kecil menengah yang mencapai 44.7 juta orang atau 99.9 persen dari total lapangan kerja pada industri manufaktur Indonesia dan mereka adalah basis sumber daya daerah. Dengan demikian, potensi ekonomi daerah ini memungkinkan untuk mengatasi masalah pengangguran, kemiskinan, dan meningkatkan lonjakan pertumbuhan ekonomi nasional (Sebayang dan Kuncoro, 2011)

Keberhasilan potensi ekonomi daerah akan bergantung pada bagaimana daerah menyusun dan mengelola wilayahnya, termasuk meningkatkan investasi dan minat investor sesuai dengan kerangka desentralisasi fiskal, politik, dan administrasi (Mahi, 2009). Rata-rata petumbuhan ekonomi daerah pada periode desentralisasi cukup meningkat.Akan tetapi, relatif terhadap desentralisasi (seperti periode 1993-1996) pertumbuhan ekonomi setelah desentralisasi masih cukup rendah. Desentralisasi tersebut juga menghasilkan pertumbuhan daerah yang relatif tinggi, dibandingkan dengan rata-rata nasional; akan tetapi beberapa daerah membutuhkan percepatan pertumbuhan (Lewis, 2003). Pada pertengahan tahun 2000an, pertumbuhan ekonomi daerah dan distribusi pendapatan antar daerah relatif tidak mengalami perubahan (Grafik 1 dan 2).

Fakta tersebut menunjukkan pentingnya bagi pemerintah daerah untuk memfasilitasi potensi ekonomi daerah demiterwujudnya peningkatan standar hidup yang berkelanjutan (Kaufmann et al., 2005; Knack, 2003). Makalah ini akan mengkaji dinamika tata kelola perekonomian daerah khususnya kabupaten/kota di Indonesia. Pembahasan pada makalah ini akan bermula dari tinjauan literatur yang terkait dengan tata kelola. Kemudian dilanjutkan dengan menelusuri bukti-bukti empiris yang berhubungan dengan pengaruh tata kelola terhadap 


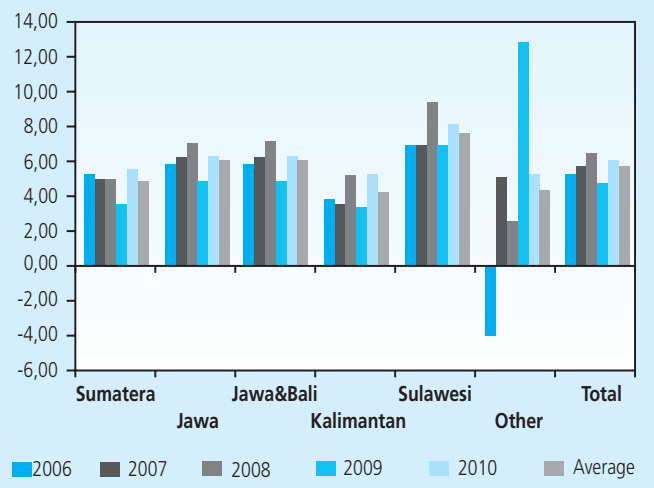

Grafik 1

Pertumbuhan Pendapatan Daerah



Grafik 2

Distribusi Pendapatan Daerah

kinerja ekonomi daerah. Penafsiran data untuk Indonesia berada pada bagian selanjutnya. Yang terakhir adalah penarikan kesimpulan.

\section{TEORI}

Literatur ekonomi politik memberikan banyak penjelasan tentang tata kelola yang hingga saat ini masih dalam proses menuju pada sebuah konsensus umum. Secara luas, tata kelola bermakna tradisi dan lembaga yang menentukan bagaimana kebijakan dilaksanakan dalam sebuah negara (Kaufmann et al., 2000). Menurut Weiss (2005), tata kelola berkaitan dengan strategi, proses, metode, dan mekanisme dalam mengelola negara dan memenuhi permintaan serta kepentingan masyarakat.

Weiss (2005) lebih jauh menjelaskan tata kelola yang baik berkaitan dengan demokrasi dan pemenuhan hak-hak sipil, dengan transparansi, dengan peraturan hukum, dan dengan pelayanan publik yang efisien. Tata kelola juga melibatkan interaksi institusi publik maupun swasta dengan masyarakat. Demikian pula Chibba (2009) yang menjelaskan bahwa masalahmasalah tata kelola merupakan bagian dari masyarakat yang terintegrasi sejak adanya peradaban, dan khususnya menjunjung nilai-nilai tertentu, etika, dan aturan yang berlaku, dan keadilan yang harus ditegakkan, bagaimana masyarakat diatur, dan siapa yang harus memegang kekuasaan dan kewenangan.

Beberapa definisi di atas saling melengkapi satu sama lain dan secara jelas mengemukakan gagasan utama dari tata kelola. Tapi, definisi-definisi tersebut masih berada pada wilayah politik atau tidak begitu memiliki makna secara ekonomi. Pada konteks ekonomi, Dixit (2001) tata kelola perekonomian terdiri dari proses yang mendukung aktifitas ekonomi dan transaksi ekonomi dengan melindungi hak-hak kepemilikan, melaksanakan kontrak, dan bersama-sama 
bekerja untuk menghasilkan infrastruktur fisik dan keorganisasian yang tepat. Tong (2011) secara sederhana mendefinisikan kualitas tata kelola sebagai kapasitas pemerintah untuk menginternalisasi eksternalitas. Walaupun definisi Dixit dan Tong masih bersifat umum, mereka memberikan permulaan yang sangat berguna untuk menelusuri pemahaman yang lebih dalam.

Beberapa ahli agak menyempitkan pola pandangnya dengan menguraikan tata kelola menjadi konsep yang terpisah, seperti korupsi (We, 2000), transparansi (Kaufmann et al., 2000), peraturan (Djankov et al., 2002), dan pengadaan barang publik (Kaufmann et al., 2005), yang mana setiap mereka masih mengandung banyak jenis dan pencetus kebijakan interaksi yang berbeda. Ahli-ahli lain melihat dari sudut pandang mikro di mana kebijakan individu seperti prosedur registrasi bisnis telah dipisahkan dan dilakukan secara terpisah dari tata kelola lain dalam masyarakat (lihat: contohnya Helpman (2008) untuk beberapa kajian terkini).

Berdasarkan beberapa penjelasan di atas, satu hal penting yang dapat disimpulkan adalah kemampuan pemerintah mengelola urusan administrasinya akan membawa dampak yang sangat kuat pada aktifitas pelaku ekonomi. Walaupun konsep tata kelola tidaklah baru, konsep tersebut sama tuanya dengan peradaban manusia, sayangnya, faktor ini dianggap telah ada pada model pertumbuhan ekonomi neoklasik tradisional, seperti apa yang telah diungkapkan Solow (1996), Cass (1965), dan Koopmans (1965) (lihat: Romer, 1996). Teori pertumbuhan endogen yang dikemukakan oleh Romer $(1986 ; 1990)$ dan Lucas $(1988)$ mencoba untuk menggabungkan faktor inovasi tanpa menjelaskan bagaimana dan di mana inovasi diciptakan. Inovasi teknologi hanya dapat diciptakan karena lingkungan institusional.

Benang merah antara institusi, pemerintahan, dan kinerja ekonomi telah menjadi subyek yang sangat sering didiskusikan selama 25 tahun terakhir. Apa yang telah dilakukan North (1981) dapat dianggap sebagai pionir ide yang berkembang tentang pemicu kapabilitas pemerintah. Menurut North (1981), institusi/lembaga merupakan aturan main masyarakat atau, secara formal, kendala-kendala/batasan-batasan yang terjadi secara manusiawi yang membentuk interaksi manusia. Kendala/batasan tesebut akan berpengaruh melalui sebuah dorongan (North, 1990). Dorongan yang dimaksudkan di sini adalah mengkondisikan kesediaan pelaku ekonomi untuk menerima aturan main tersebut.

Oleh karenanya, banyak ahli ekonomi mengembangkan ide North dalam menciptakan sebuah dorongan bagi pertumbuhan ekonomi dengan menggunakan perspektif yang berbeda. Inti tujuannya sama, seperti mengurangi ketidakpastian dan mendorong efisiensi. Ekonomi politik baru (new political economy), contohnya, membantah pentingnya program-program penyesuaian struktur dengan menghilangkan motif rent seeking dan korupsi (Krueger, 1974; Posner, 1975; Bhagwati, 1982; Bardhan, 1984; Colander, 1984; Alt dan Shepsle, 1990; Lal dan Myint, 1996; Bates, 2001).

Sejalan dengan Ekonomi Politik Baru, Lembaga Ekonomi Baru (dicetuskan oleh Williamson, 1975; 1985) telah menyatakan teori ekonomi yang mengidentifikasi kemampuan 
tata kelola yang harus dimiliki oleh negara demi terciptanya efisiensi pasar. Intinya adalah Lembaga Ekonomi Baru menekankan pentingnyamarket-enhancing government melalui perlindungan pelaksanaan kontrak dan hak kepemilikikan. Singkatnya, Acemoglu, Hohnson, dan Robinson (2005) menyimpulkan bahwa tata kelola pemerintah yang baik merupakan dasar utama dari pertumbuhan ekonomi.

Walaupun tidak ada sebuah tata kelola tanpa pemerintah, tata kelola tidak bisa sematamata dipandang sebagai hasil tapi juga sebagai serangkaian hubungan dan proses yang menghasilkan. Teknisnya, beberapa ahli mengembangkan indeks untuk mengakomodasi konsep-konsep tata kelola ekonomi yang sangat bervariasi di atas (contohnya Knack dan Keefer, 1995, 1997; Kaufmann et al., 1999, dan Kaufmann et al., 2005). Bank Dunia (2005) telah menyimpulkan enam indikator tata kelola secara luas:

1. Suara dan Akuntabilitas - menilai hak-hak politik, sipil, dan manusia.

2. Ketidakstabilitas Politik dan Kekerasan - mengukur tingkat kemungkinan adanya ancaman kekerasan terhadap, atau perubahan pada, pemerintah, termasuk terorisme.

3. Efektifitas Pemerintah - mengukur kompetensi birokrasi dan kualitas pelayanan masyarakat.

4. Beban Peraturan - mengukur sejauh mana dampak dari kebijakan pasar yang tidak bersahabat

5. Peraturan Hukum - mengukur kualitas pelaksanaan kontrak, polisi, dan pengadilan, serta kemungkinan adanya kriminalitas dan kekerasan

6. Kontrol Korupsi - mengukur sejauh mana kekuatan publikatas keuntungan pribadi, termasuk korupsi skala besar dan kecil serta state capture.

Enam indikator di atas menunjukkan bahwa kualitas tata kelola merupakan penjabaran yang cukup rumit.Bentuknya dapat bermacam-macam dan kemungkinan adanya trade-off antara dimensi tata kelola yang berbeda. Tong (2011) mengemukakan bahwa tata kelola yang baik sering dimaknai sebagai pemerintahan yang efektif, yakni merupakan konsep yang multidimensional dan luas. Berbagai macam indikator tata kelola yang telah banyak digunakan tidak mencakup seluruh ide dari tata kelola tersebut. Thomas (2007) mengemukakan indikatorindikator tersebut merupakan hasil dari penggabungan "gagasan-gagasan mengenai tata kelola" yang diajukan oleh penggagasnya. Quibria (2006) mengemukakan bahwa tata kelola sering "digunakan sebagai konsep paying untuk menggabungkan seluruh ide yang, walaupun terkait, berbeda".

Terlepas dari dimensi tata kelola yang berbeda, titik temu dari seluruh pandangan tersebut menghasilkan rangkaian prioritas kebijakan yang kita kenal sebagai agenda tata kelola yang baik. Studi empiris yang berkaitan dengan tata kelola yang baik telah berjalan secara luas. Secara umum, mereka setuju untuk memisahkan hubungan bahkan hubungan sebab akibat antara lembaga pengelola (pemerintah) dan kinerja ekonomi. 
Pada level antar negara, beberapa faktor penentu yang telah teridentifikasi pada penelitian-penelitian tertentu adalah hak kepemilikan dan aktifitas wirausaha (Galiani dan Scargrodsky, 2006; Di Tella, 2007; Fields, 2007; Banerjee dan lyer, 2005; dan Malesky dan Taussig, 2009). Mengistudan Adhikary (2011) percaya bahwa tata kelola yang baik merupakan faktor penentu bagi investor untuk menanamkan modalnya khususnya di negara-negara Asia.

Beberapa ahli telah merancang analisis sub-nasional yang cerdasterkait dampak korupsi terhadap kinerja perekonomian (Fisman, 2001; Golden dan Picci, 2005; Di Tella dan Schargrodsky, 2003; dan Olken, 2007), pentingnya hubungan bisnis negara (Cali, 2009) serta prediksi korupsi (Malesky dan Samphantharak, 2008). Ardagna dan Lusardi (2008) menjelaskan bahwa lembaga pelaksana kontrak yang lebih baik akan meningkatkan pangsa wisarusaha yang selalu berorientasi pada pertumbuhan. Dengan menggunakan variasi lembaga-lembaga antar provinsi di Mexico, Laeven dan Woodruff (2007) menemukan hubungan yang signifikan antar lembaga kontrak yang lebih baik dengan tingkat pertumbuhan perusahan yang lebih tinggi.

Kebanyakan dari studi di atas berfokus pada data antar negara yang berbeda dari Indonesia yang memiliki struktur ekonomi dan budaya yang berbeda. Menurut Lewis (2003), kinerja perekonomi daerah yang ada di Indonesia sangat bervariasi sejak desentralisasi pada 2001. Beberapa daerah/kota telah menunjukkan kemajuan ekonomi yang hebat, investasi yang kuat, dan lapangan pekerjaan yang luas. Tapi banyak daerah lain yang cukup tertinggal, gagal untuk menumbuhkan perekonomian secara keseluruhan. Kemudian terdapat fakta bahwa kebijakan otoritas daerah memiliki elemen penting untuk menunjang kualitas iklim investasi daerah.

Kuncoro dan Suryanto (2003) mengemukakan bahwa terdapat persistensi yang cukup tinggi pada posisi relatif pendapatan daerah, sejalan dengan rendahnya pergerakan distribusi pendapatan. Daerah kaya cenderung berpolarisasi secara bertahap, yang dapat dihubungkan dengan eksternalitas yang terkait dengan lokalisasi atau dengan kedekatan daerah-daerah lain di pulau Jawa. Pepinsky dan Wihardja (2009) juga mengemukakan bahwa perbedaan kinerja perekonomian antar kabupaten/kota disebabkan oleh heterogenitas sumber daya, imobilitas faktor dan kualitas kelembagaan. Penemuan tersebut sejalan dengan studi yang dilakukan oleh Mahi (2009). la menemukan bahwa walaupun konsentrasi industri geografis menurun secara bertahap (khususnya di Jawa dan Bali) pasca desentralisasi, terdapat dampak yang buruk terhadap kualitas pembangunan ekonomi daerah. la juga mengemukakan bahwa iklim investasi memainkan peranan yang sangat penting pada konsentrasi geografis.

Istiandari (2009) mempelajari kinerja perekonomian daerah dan menghubungkannya dengan pendapatan daerah serta tingkat kemiskinan. Menurut hasil kajiannya, kebanyakan daerah di Jawa memiliki tata kelola yang lebih baik dalam memberikan dampak positif terhadap kesejahteraan.la juga menemukan adanya kesenjangan yang sangat jauh terkait pelaksanaan 
tata kelola antar kabupaten/kota. Yang terkini, McCulloch dan Malesky (2010) menelusuri data baru tentang persepsi perusahaan terhadap kualitas tata kelola perekonomian di 243 daerah di seluruh Indonesia untuk mengukur dampak dari sembilan dimensi tata kelola yang berbedapada pertumbuhan kabupaten/kota. Anehnya, mereka hanya menemuan sedikit fakta hubungan yang kuat antara kualitas tata kelola dan kinerja perekonomian daerah.

Sejumlah studi di atas mengemukakan bahwa tata kelola perekonomian daerah sangat berhubungan dengan kinerja perekonomian daerah. Jadi, sangat pentingbagi kita untuk menelusuri tata kelola perekonomian daerah. Dari sudut pandang peneliti, ini adalah uji yang sangat penting terhadap validitas Lembaga Ekonomi Baru dan Ekonomi Politik Baru saat dibenturkan dengan model pertumbuhan endogen dan neoklasik. Pembuat kebijakanjuga akhirnya menganggap tata kelola sebagai aspek penting dan dimensi baru pada kajian kebijakan dan administrasi serta perencanaan untuk negara secara global. Dan, analisis daerah semacam ini menjadi sangat relevan bagi kebijakan karena banyak negara yang bergerak menuju kepada desentralisasi politik, fiskal, dan administratif yang lebih besar. Memang pemerintah pusat dan pendonor memiliki tujuan untuk meningkatkan tata kelola pada level daerah secara mendasar yang akan meningkatkan pertumbuhan ekonomi daerah.

Makalah ini berkontribusi terhadap literatur tata kelola pemerintah daerah dan empiris terhadap Indonesia. Pendakatan kami sejalan dengan gagasan Istiandari (2009) dan McCulloch dan Malesky (2010), walaupun terdapat tiga perbedaan yang sangat signifikan. Pertama, kami mengamati indeks tata kelola, bukan secara langsung mengukur indikator tata kelola terhadap pertumbuhan ekonomi daerah. Kedua, kami berfokus pada dinamika transisi indeks tata kelola relatif dengan menggunakan metode non parametrik (seperti fungsi densitas Kernel) untuk mengenali pola distribusi tata kelola antar negara. Ketiga, kami berfokus pada dinamika transisi distribusi tata kelola relatif dengan menggunakan rantai Markov. Makalah ini juga mendeteksi adanya perubahan tertentu pada pergerakan tata kelola perekonomiandaerah berdasarkan indeks peringkatnya. Penggunaan rantai Markov telah secara intensif digunakan dalam penelitian bisnis yang bertujuan untuk memberikan analisis mendalam terhadap proses dinamika tata kelola perekonomian daerah di Indonesia.

\section{METODOLOGI}

Untuk lebih memahami bentuk dari distribusi relatif tata kelola daerah atau bagaimana perkembangannya selama beberapa tahun terakhirdi Indonesia, tata kelola daerah relatif Kernels pada periode berbeda diukur sehingga bentuk dan dinamika inter-temporalnya dapat dikaji. Alat pengamatan estimator Kernel - yang merupakan peringkat relatif dari indeks tata kelola perekonomian daerah - merupakan fungsi distribusi yang diuji yang mana pengamatannya sepertinya telah dilakukan (untuk detailnya, lihat Siverman (1986)). Secara matematis, estimator Kernel dapat dijabarkan sebagai berikut : 


$$
f(x)=1 / N h \Sigma j=1 \quad--->\quad N K[(x-X j) / h]
$$

di mana,

$\mathrm{Xj}=$ data

$\mathrm{N}=$ jumlah poin data

$\mathrm{h}=$ window width / smoothing parameter

$\mathrm{K}=$ Kernel/fungsi bobot (diasumsikan berdistribusi normal pada makalah ini).

Pengukuran densitas Kernel membutuhkan beberapa langkah (lihat Silverman, 1986). Langkah pertama, setiap tahun, sub-indeks pada setiap kabupaten/kota di-skala ulang sehingga distribusi dibatasi untuk berada pada nilai positif. Karena melalui konstruksi, sub-indeks ratarata nasional selalu bernilai 1 (100 persen).

Langkah selanjutnya, untuk sejumlah besar poin yang berada pada interval, frekuensi relatif, contohnya ketidakpastian, yang mana tiap nilainya bisa saja ada/terjadi, telah diukur. Probabilitas setiap poin dihitung sebagai rerata tertimbang jarak poin-poin tersebut dari pendapatan relatif yang ada di seluruh daerah, dengan bobot yang diambil dari distribusi normal atau Gaussian yang terpusat pada poin tersebut. Bobot diambil dari distribusi Epanechnikov, metode pembobotan lain yang sering digunakan, tidak menghasilkan perbedaan yang begitu besar terhadap bentuk estimasi Kernels.

Pada langkah ketiga, frekuensi relatif poin-poin ini disaring untuk noise dengan menggunakan prosedur Silverman (1986). Pengumpulan frekuensi relatif yang telah disaring membentuk tata kelola daerah relatif Kernel di tahun tersebut. Area distribusinya dinormalisasikan sebesar 100 (persen). Estimator Kernel menyampaikan kepada kita seperti apa penilaian tata kelola, secara rata-rata, merupakan pecahan tertentu dari penilaian tata kelola rata-rata nasional pada tahun tertentu.

Sebagaimana disampaikan di atas, distribusi densitas Kernel sangat membantu untuk mengidentifikasi bentuk distribusi tata kelola relatif atau bagaimana perkembangannya selama bertahun-tahun. Tapi ini tidak dapat memprediksi setiap probabilitas transisi distribusi yang akan berpusat pada satu titik terhadap setiap kondisi yang stabil. Rantai Markov menyarankan probabilitas transisi dari setiap distribusi mencapai kondisi yang stabil. Proses Markov dapat dianggap sebagai kasus khusus dari proses stokastik. Proses tersebut dapat diartikan sebagai kelanjutan waktu yang berbeda dan berhubungan dengan kondisi-kondisi yang berbeda atau berlanjut.

Menurut Amemiya (1985), model Markov dapat dicirikan dengan dua poin di bawah ini:

- Sebuah rangkaian variabel random biner yang nilai berikut :

$\mathrm{y}_{\mathrm{j}}(\mathrm{t})=1$ jika unit $i^{\text {th }}$ adalah kondisi $j$ di waktu $t$ 
dan

$\mathrm{y}_{\mathrm{j}}(\mathrm{t})=0$ atau, untuk $i=1, \ldots, \mathrm{n}$

Jika, pada konteks waktu yang berbeda, untuk setiap unit $i$, distribusi faktor $\mathrm{y}_{\mathrm{j}}(\mathrm{t})$ hanya bergantung sepenuhnya pada $\mathrm{y}_{\mathrm{i}}(\mathrm{t}-1)$, maka hal tersebut adalah proses Markov waktu diskritorde pertama.

- Serangkaian probabilitas transisi, di mana $\mathrm{pi}_{\mathrm{jk}}(\mathrm{t})$ merupakan probabilitas unit $i$ yang ada pada kondisi $j$ pada waktu (t-1) dan langsung berpindah ke kondisi $k$ pada waktu $t$. Jika rangkaian kondisi tersebut terbatas dan tidak dapat tidak dapat di-angka-kan maka seluruh probabilitas transisi dapat disusun pada bentuk matriks Markov. $\mathrm{Pi}=\{$ pijk $(\mathrm{t})\}$, adalah total dari seluruh elemen yang akan ditambahkan menjadi satu.

Asumsikan $\mathrm{p}(\mathrm{t})$ adalah vektor yang menjelaskan distribusi unit-unit seluruh kondisi berbeda pada waktu t. Maka akan menjadi

$$
\mathrm{p}_{\mathrm{j}}(\mathrm{t})=1 / \mathrm{n} \Sigma_{\mathrm{i}-1-\mathrm{-}-\mathrm{n}} \mathrm{yi}_{\mathrm{j}}(\mathrm{t})
$$

di mana n adalah jumlah unit. Model seperti ini disebut rantai Markov.

Kemudian, jika probabilitas transisi tidak bergantung pada waktu atau unit tersebut, model tersebut disebut homogen dan stasioner. Dapat ditunjukkan bahwa, pada situasi yang cukup baik, terdapat semacam matriks jangka panjang, atau 'ergodic' yang unik dari probabilitas transisi $\mathrm{P}^{\infty}$ dan vektor korespondensi probabilitas ekuilibrium yang berkaitan dengan rantai Markov yang stasioner. Dengan kata lain, jika kita mendenotasikan matriks transisi sebagai $\mathrm{P}=$ $\left\{\mathrm{p}_{\mathrm{jk}}\right\}$, maka vektor ekuilibrium 'ergodic' nya menjadi $\mathrm{p}$, yang menjelaskan

$$
\pi=p^{\prime} \pi
$$

sehingga

$$
\pi_{\mathrm{j}} \geq 0 \text { dan } \Sigma_{\mathrm{j} \in \mathrm{E}} \pi_{\mathrm{j}}=1
$$

maka

$$
\lim _{t \rightarrow \infty} p_{j}(t)=\pi_{j}
$$

Dengan kata lain, pada jangka panjang, elemen transisi matriks akan mencapai kondisi alami j dengan probabilitas $\pi_{\mathrm{j},}$ terlepas dari posisi awal. Jika kita melihat jumlah kondisi terbatas (karena ditentukan, contohnya, dengan level peringkat indeks yang berbeda), pergerakan unitunit antar kondisi dapat ditelusuri dengan mudah dan tentunya probabilitas transisi matriks bisa didapatkan. 
Matriks ini akan menunjukkan dinamika perilaku unit-unit, karena transisi matriks mengungkapkan, dengan sangat jelas, dan probabilitas sebuah unit yang bermula pada kondisi tertentu dan berakhir pada kondisi yang sama atau berbeda. Perlu diperhatikan bahwa, dengan cara menggunakan rantai Markov pertama, dapat diasumsika secara implisit bahwa semua informasi yang relevan mengenai kinerja masa lalu daerah tertentu disesuaikan pada prinsip yang mendasari arah kondisi dimana sebuah daerah cukup stabil dari waktu ke waktu.

Kita dapat menggunakan, dengan tetap merujuk kepada Amemiya (1985), aturan bahwa estimator maximum likelihood pada probabilitas transisi dapat dihitung sebagai berikut:

$$
\mathrm{P}_{\mathrm{jk}}=\frac{\sum \mathrm{s}_{\mathrm{jk}}(\mathrm{t})}{\sum_{\mathrm{t}} \sum_{\mathrm{k}} \mathrm{s}_{\mathrm{jk}}(\mathrm{t})}=\frac{\sum_{\mathrm{t}} \sum_{\mathrm{i}} \mathrm{yi}_{\mathrm{j}}(\mathrm{t}-1) \mathrm{yi}_{\mathrm{k}}(\mathrm{t})}{\sum_{\mathrm{t}} \sum_{\mathrm{k}} \Sigma_{\mathrm{i}} \mathrm{yi}_{\mathrm{j}}(\mathrm{t}-1) \mathrm{yi}_{\mathrm{k}}(\mathrm{t})}
$$

Dimana $\mathrm{s}_{\mathrm{jk}}(\mathrm{t})$ merupakan sejumlah unit yang berubah dari kondisi j ke kondisi $\mathrm{k}$ pada periode t. Vektor ergodic, yang menggambarkan distribusi indeks unit pada jangka panjang, didapatkan dengan cara iterasitransisi matriks. Jika vektor densitas ergodic hanya memiliki satu maksimum, maka terdapat beberapa tingkat konvergensi. Sebaliknya, jika strukturnya cenderung bersifat bi-modal (atau bahkan tri-modal), maka bisa saja merujuk ke beberapa tingkat polarisasi.

Hakikat dari analisis ini mengemukakan bahwa hasil yang berkaitan dengan distribusi indeks tata kelola kondisi yang stabil seharusnya dicermati dengan hati-hati. Perhitungan probabilitas jangka panjang secara implisit berimplikasi bahwa probabilitas historis akan berulang di masa depan. Dengan kata lain, tidak akan ada guncangan yang merubah arah perekonomian dan merubah tren saat ini. Hal ini jelas tidak realistis; tidak alasan untuk mempercayai bahwa lembaga, tingkat kemajuan teknologi, hakikat dari sumber daya manusia, dan faktor penting lainnya yang menentukan indeks tata kelola perekonomian daerah akan sama saja dari waktu ke waktu.

\section{HASIL DAN ANALISIS}

Makalah ini menggunakan data tata kelola perekonomian daerah yang dipublikasikan oleh Komisi Pengawas Pelaksanaan Otonomi Daerah (KPPOD). Sejak 2007, Asia Foundation, bekerja sama dengan NGO di Indonesia, KPPOD, telah melansir sejumlah data tentang persepsi perusahaan yang mengukur kualitas tata kelola perekonomian daerah di 243 daerah di seluruh wilayah di negeri ini. Data tersebut berdasarkan representasi pengambilan sampel secara random sebanyak 12,000 perusahaan dan 729 asosiasi bisnis di seluruh kabupaten/kota tersebut. Perusahaan yang dipilih mencakup industri kecil (yang memiliki 10-19 pekerja), menengah 
(yang memiliki 20-99 pekerja), dan besar (yang memiliki lebih dari 100 pekerja). Proporsinya adalah masing-masing 50, 45, dan 5 persen.

Kami menggunakan data 2007 dan membandingkannya dengan data terbaru 2011. Indikator tata kelola ekonomi daerah yang digunakan oleh KPPOD meliputi 9 elemen berdasarkan kriteria Bank Dunia :

1. Aksesibilitas Lahan

2. Izin Usaha

3. Interaksi antara Pemerintah Daerah dengan Sektor Swasta

4. Program Pengembangan Bisnis

5. Kemampuan dan Integritas Pejabat Pemerintah Daerah

6. Pajak dan Retribusi Daerah serta Biaya Transaksi lainnya

7. Manajemen Infrastruktur

8. Resolusi Keamanan dan Konflik

9. Kualitas Peraturan Daerah

Setiap kriteria kemudian dihitung ke masing-masing sub-indeks serta total indeks. Dalam menyusun indeks tersebut KPPOD menggunakan pertimbangan, proses hirarki analitik, dan diakhiri dengan diskusi kelompok. Setiap indeks berjarak 0 sampai 100 poin. Makin tinggi indeks tersebut, makin baik tata kelolanya. Berdasarkan total indeks, KPPOD kemudian menyusun seluruh daerah secara berurutan seperti disajikan pada Tabel 1. Selama 2007-2011, Blitar berada pada peringkat pertama di kedua periode tersebut. Magetan dan Probolinggo juga berada pada 10 peringkat terbaik.

\begin{tabular}{|c|c|c|c|c|}
\hline \multicolumn{5}{|c|}{$\begin{array}{c}\text { Tabel } 1 . \\
\text { Total Indeks } 10 \text { Peringkat Terbaik Tata Kelola Perekonomian Daerah 2007-2011 }\end{array}$} \\
\hline Rank & Region & 2007 & Region & 2011 \\
\hline 1 & Kabupaten Blitar & 76,00 & Kabupaten Blitar & 80,50 \\
\hline 2 & Kota Magetan & 75,40 & Kota Lampung Utara & 79,00 \\
\hline 3 & Kabupaten Prabumulih & 74,70 & Kabupaten Probolinggo & 78,40 \\
\hline 4 & Kota Musi Banyu Asin & 74,30 & Kabupaten Batu & 76,30 \\
\hline 5 & Kota Jembrana & 73,70 & Kota Sorong & 74,60 \\
\hline 6 & Kota Tuban & 73,40 & Kota Bangka Tengah & 74,30 \\
\hline 7 & Kota Lumajang & 72,00 & Kota Magetan & 73,90 \\
\hline 8 & Kota Madiun & 72,00 & Kota Probolinggo & 73,80 \\
\hline 9 & Kabupaten Probolinggo & 71,50 & Kabupaten Solok & 73,20 \\
\hline 10 & Kota Gianyar & 71,30 & Kabupaten Padang Panjang & 73,10 \\
\hline
\end{tabular}




\begin{tabular}{c|c|r|r|r|r}
\multicolumn{2}{c}{ Tabel 2. } \\
\multicolumn{2}{c}{ Statistik Deskriptif Total Indeks Tata Kelola Prekonomian Daerah 2007 - 2011 } \\
\hline \multirow{3}{*}{2007} & Mean & Jawa & Luar Jawa & Kabupaten & Kota \\
\cline { 2 - 6 } & Std. Dev & 64,32 & 59,82 & 61,75 & 61,70 \\
\cline { 2 - 6 } & Obs & 4,85 & 6,76 & 6,62 & 6,38 \\
\hline \multirow{3}{*}{2011} & Mean & 102 & 141 & 55 & 188 \\
\cline { 2 - 6 } & Std. Dev & 67,11 & 61,79 & 65,94 & 62,12 \\
\cline { 2 - 6 } & Obs & 6,12 & 7,23 & 5,95 & 7,43 \\
\hline
\end{tabular}

Tabel 2 menjabarkan dengan lebih rinci menjadi dua ciri utama daerah. Merujuk kepada pulau-pulau besar, rata-rata total indeks tata kelola perekonomian daerah di Jawa (64.32) lebih tinggi dari luar Jawa (59.82). Tidak ada perubahan di tahun 2011. Indeks tata kelola perekonomian daerah di Jawa meningkat lebih cepat daripada luar Jawa. Nampaknya Jawa, dimana secara geografis industri berpusat, relatif memiliki tata kelola perekonomian yang lebih baik. Konsekuensinya, terdapat dampak buruk terhadap pemerataan pembangunan ekonomi regional seperti yang dikemukakan oleh Mahi (2009).

Berdasarkan administrasi wilayah, rata-rata tata kelola perekonomian daerah di kabupaten (61.75) relatif sama dengan kota (61.70). Akan tetapi, pada tahun 2011, rata-rata tata kelola perekonomian daerah di kabupaten tumbuh lebih tinggi dibandingkan dengan kota, sejalan dengan kajian yang dilakukan oleh Istiandari (2009). Selain itu, variabilitas rata-rata tata kelola perekonomian daerah di kota lebih besar dibandingkan kabupaten yang terindikasi melalui standar deviasi yang lebih tinggi terhadap mean ratio. Hal ini mengimplikasikan adanya ketidasamaan tata kelola perekonomian di Jawa-Luar Jawa atau di kabupaten-kota, sejalan dengan ketidakmerataan pendapatan daerah seperti yang ditemukan oleh Kuncoro dan Suryanto (2003).

Tabel 3 menyajikan statistik deskriptif dari 9 sub-indeks untuk tahun 2007. Yang tertinggi adalah angka pada Kualitas Peraturan Daerah (X9, 84.22). Dua angka terendah adalah Program Pengembangan Usaha $(X 4,43.04)$ dan Interaksi antara Pemerintah Daerah dengan Sektor Swasta $(X 5,56.92)$. Secara rata-rata total indeks tata kelola perekonomian daerah cukup relatif kurang lebih 61.72 dan standar deviasi 6.42 poin. Melihat koefisien variasi (CV. standar deviasi terhadap mean ratio), seluruh indeks tidak bervariasi dari nilai rata-ratanya.

Tabel 3 juga menunjukkan bentuk distribusi. Seluruh sub-indeks agak miring ke kiri, ditunjukkan oleh nilai negatif kemiringan (kecuali X4, Program Pengembangan Usaha). Terkait ketajaman, frekuensi poligon agak berbentuk mesokurtic seperti disajikan oleh nilai kurtosis kurang lebih 3. Sub-Indeks Kualitas Peraturan Daerah (X9)adalah pengecualian. Nilai kurtosis adalah yang tertinggi, 8.87, memperlihatkan bentuk leptokurtik dari frekuensi poligonnya. 
Tabel 3.

Statistik Deskriptif Sub-Indeks Tata Kelola Perekonomian Daerah 2007

\begin{tabular}{|c|c|c|c|c|c|c|c|c|c|c|}
\hline Sub-Indeks & $\mathrm{X} 1$ & $\mathrm{X} 2$ & X3 & X4 & X5 & X6 & $\mathbf{X 7}$ & X8 & X9 & Total \\
\hline Mean & 71,26 & 59,95 & 55,42 & 43,04 & 56,92 & 69,55 & 65,57 & 60,01 & 84,22 & 61,72 \\
\hline Median & 71,70 & 60,00 & 55,40 & 41,80 & 57,40 & 70,50 & 67,00 & 61,90 & 88,20 & 62,10 \\
\hline Max. & 99,40 & 84,60 & 80,10 & 86,50 & 87,90 & 96,10 & 89,00 & 96,70 & 100,00 & 76,00 \\
\hline Min. & 39,70 & 32,20 & 26,30 & 15,00 & 23,90 & 27,30 & 26,30 & 27,40 & 1,10 & 41,40 \\
\hline Std. Dev. & 10,25 & 8,33 & 9,84 & 12,14 & 10,82 & 12,24 & 12,06 & 11,51 & 13,92 & 6,42 \\
\hline $\mathrm{CV}$ & 0,14 & 0,14 & 0,18 & 0,28 & 0,19 & 0,18 & 0,18 & 0,19 & 0,17 & 0,10 \\
\hline Kemiringan & $-0,39$ & $-0,20$ & $-0,19$ & 0,58 & $-0,09$ & $-0,32$ & $-0,59$ & $-0,18$ & $-1,93$ & $-0,43$ \\
\hline Kurtosis & 3,85 & 3,66 & 3,16 & 3,86 & 3,57 & 2,94 & 2,98 & 2,87 & 8,87 & 3,08 \\
\hline J-B test & 13,56 & 6,09 & 1,67 & 21,22 & 3,62 & 4,13 & 14,30 & 1,52 & 499,92 & 7,62 \\
\hline Prob. & 0,0011 & 0,0475 & 0,4337 & 0,0000 & 0,1639 & 0,1267 & 0,0008 & 0,4669 & 0,0000 & 0,0222 \\
\hline Obs. & 243 & 243 & 243 & 243 & 243 & 243 & 243 & 243 & 243 & 243 \\
\hline
\end{tabular}

Tabel 4 menunjukkan statistik deskriptif 2011. Hal yang menarik adalah rata-rata indeks tata kelola dari Pajak dan Retribusi Daerah Serta Biaya Transaksi Lainnya (X6) saat ini menjadi yang tertinggi (81.82) di tahun 2011 sedikit lebih tinggi dari Kualitas Peraturan Daerah (X9). Jelas terdapat peningkatan yang signifikan bagi pemerintah daerah merevisi peraturan daerah mereka. Berdasarkan KPPOD (2011), selama 2001-2011 pemerintah pusat (seperti Kementerian Keuangan) memeriksa 13.252 berkas peraturan daerah, Kementerian Hubungan Dalam Negeri merekomendasikan pembatalan 4.885 berkas. Kementerian Dalam Negeri telah secara resmi membatalkan hanya 1.843 peraturan daerah khususnya yang berkenaan dengan pungutan dan pajak. Berkas peraturan daerah yang tersisa masih belum diputuskan apakah dibatalkan, dijalankan, atau ditangguhkan.

Tiga rata-rata sub-indeks terendah berikutnya adalah X4 (Program Pengembangan Usaha, 38.57), X3 (Interaksi antara Pemerintah Daerah dengan Sektor Swasta, 50.90), dan X5 (Kemampuan dan Integritas Pejabat Pemerintah Daerah, 50.94). Yang terakhir agak mirip dengan tahun 2007. Hal ini mengimplikasikan kemampuan dan integritas pejabat pemerintah daerah dalam berinteraksi dengan sektor swasta untuk mempromosikan bisnis atau usaha cukup rendah walaupun mereka berhasil mempertahankan resolusi keamanan dan konflik di daerah mereka.

Rata-rata seluruh indeks tata kelola perekonomian daerah adalah 62.76 pada tahun 2011, hampir sama dengan 61.72 pada tahun 2007. Secara umum, seluruh sub-indeks dan total indeks tata kelola perekonomian daerah cenderung stagnan selama periode 2007-2011. Inspeksi 


\begin{tabular}{|c|c|c|c|c|c|c|c|c|c|c|}
\hline \multicolumn{11}{|c|}{$\begin{array}{c}\text { Tabel } 4 . \\
\text { Statistik Deskriptif Sub-Indeks Tata Kelola Perekonomian Daerah } 2011\end{array}$} \\
\hline Sub-Indeks & $\mathrm{X} 1$ & X2 & X3 & $\mathrm{X} 4$ & $\times 5$ & $x 6$ & $\mathrm{X} 7$ & $\mathrm{X} 8$ & X9 & Total \\
\hline Mean & 73,77 & 62,22 & 50,94 & 38,57 & 50,90 & 81,28 & 69,18 & 67,06 & 81,13 & 62,76 \\
\hline Median & 74,90 & 61,80 & 50,70 & 37,50 & 51,60 & 82,50 & 71,00 & 68,70 & 83,80 & 63,40 \\
\hline Max. & 94,30 & 84,60 & 80,10 & 78,40 & 89,80 & 100,00 & 94,00 & 94,20 & 100,00 & 80,50 \\
\hline Min & 41,80 & 31,10 & 25,00 & 0,00 & 14,90 & 44,20 & 29,50 & 2,40 & 31,60 & 39,40 \\
\hline Std. Dev. & 11,23 & 8,57 & 9,91 & 15,84 & 12,52 & 10,77 & 12,94 & 12,28 & 11,19 & 7,31 \\
\hline $\mathrm{CV}$ & 0,15 & 0,14 & 0,19 & 0,41 & 0,25 & 0,13 & 0,19 & 0,18 & 0,14 & 0,12 \\
\hline Kemiringan & $-0,45$ & $-0,15$ & 0,12 & 0,25 & 0,06 & $-0,77$ & $-0,69$ & $-1,04$ & $-1,12$ & $-0,57$ \\
\hline Kurtosis & 2,70 & 3,63 & 3,24 & 2,88 & 3,34 & 3,58 & 3,18 & 6,36 & 4,66 & 3,33 \\
\hline J-B test & 9,24 & 4,97 & 1,13 & 2,63 & 1,28 & 27,45 & 19,89 & 159,44 & 77,67 & 14,62 \\
\hline Prob. & 0,0099 & 0,0831 & 0,5670 & 0,2686 & 0,5280 & 0,0000 & 0,0000 & 0,0000 & 0,0000 & 0,0007 \\
\hline Obs, & 245 & 245 & 245 & 245 & 245 & 245 & 245 & 245 & 239 & 245 \\
\hline
\end{tabular}

visual densitas Kernel seperti pada Gambar 3 mendukung kesimpulan awal ini. Densitas nonparametrik telah dihitung menggunakan Gaussian Kernel, dengan bandwidth optimal yang dipilih untuk setiap kasus. Di awal tahun, bentuknya mirip distribusi normal dan densitas probabilitasnya agak miring ke kanan.Perlu dicatat bahwa puncak local pada mode yang kanan, memberikan beberapa tingkat polarisasi untuk tahun ini.

Di tahun 2011, kemajuan yang dirasakan pada bagian tertinggi distribusi sangat nyata, karena probabilitas telah bergeser ke kanan sebagian. Walaupun probabilitas tidak berubah,
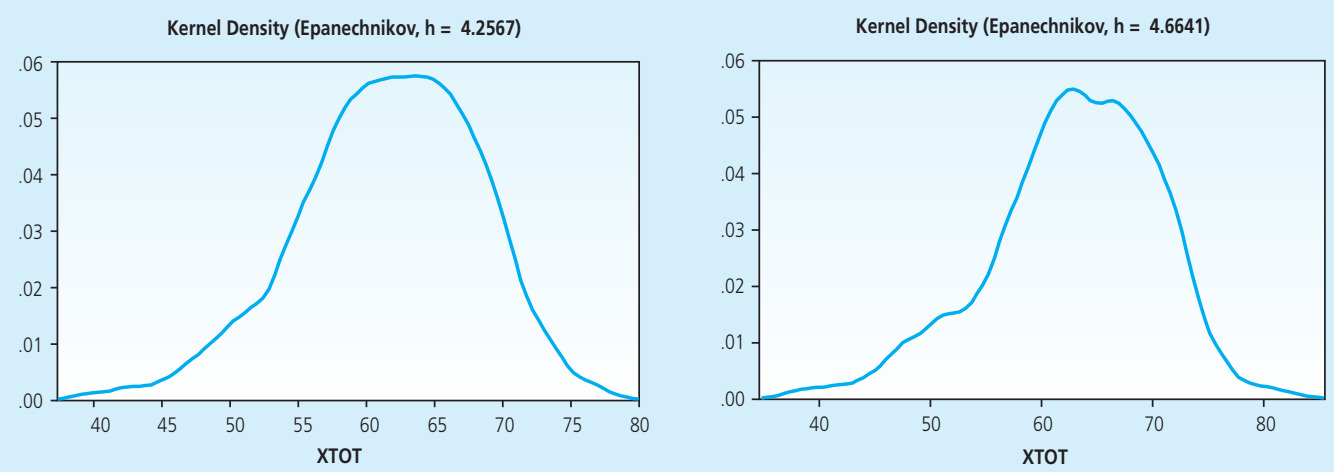

Grafik 3

Distrbusi Kernel Total Indeks Tata Kelola Perekonomian Daerah 
dua puncak lokal di tengah akhirnya muncul, menunjukkan bahwa beberapa tingkat polarisasi tata kelola daerah yang lebih tinggi pada tahun ini juga terjadi. Pada dasarnya, tidak ada perbedaan yang begitu signifikan antara bentuk distribusi indeks total tata kelola perekonomian daerah pada tahun 2007 dan 2011. Umumnya, hampir seluruh sub-indeks dan total indeks terdistribusi normal seperti yang diindikasikan oleh uji Jarque-Bera seperti disajikan sebelumnya pada tabel 3 dan 4.

Tabel 5 menyajikan simple pair wise correlations matrix antar sub-indeks tata kelola. Bagian bawah kiri adalah data 2007 dan kanan atas adalah data 2011. Hampir seluruh subindeks berkolerasi dengan hampir seluruh sub-indeks lainnya, akan tetapi, biasanya bernilai negatif dengan sub-indeks Program Pengembangan Usaha. Di tahun 2007, contohnya, subindeks X1 (Aksesibilitas Lahan) berkorelasi negatif dengan X4 (Program Pengembangan Usaha). Hal ini juga terjadi pada hubungan dengan X4, X6, X7, X8, dan X9. Hal ini mengimplikasikan bahwa lahan merupakan kendala utama bagi pembangunan ekonomi di wilayah tersebut seperti yang ditemukan oleh Mahi (2009).

\begin{tabular}{|c|c|c|c|c|c|c|c|c|c|}
\hline \multicolumn{10}{|c|}{$\begin{array}{l}\text { Tabel } 5 . \\
\text { Pair Wise Correlation antar Sub-Indeks Tata Kelola Perekonomian Daerah } 2007 \text { - } 2011\end{array}$} \\
\hline Sub-Indeks & $\mathrm{x} 1$ & $\mathrm{X} 2$ & $\mathrm{X} 3$ & $\mathrm{X} 4$ & $\times 5$ & $\mathrm{X6}$ & $\mathrm{X7}$ & $\mathrm{x} 8$ & X9 \\
\hline $\mathrm{X} 1$ & 1,00 & 0,22 & 0,23 & $-0,30$ & 0,28 & 0,49 & 0,16 & 0,48 & $-0,08$ \\
\hline $\mathrm{x} 2$ & 0,15 & 1,00 & 0,38 & 0,21 & 0,20 & 0,25 & 0,42 & 0,33 & 0,02 \\
\hline $\mathrm{X3}$ & 0,10 & 0,55 & 1,00 & 0,22 & 0,69 & 0,11 & 0,35 & 0,38 & $-0,04$ \\
\hline $\mathrm{X} 4$ & $-0,37$ & 0,16 & 0,20 & 1,00 & 0,06 & $-0,23$ & 0,13 & $-0,09$ & 0,00 \\
\hline$\times 5$ & 0,18 & 0,51 & 0,78 & 0,12 & 1,00 & 0,15 & 0,26 & 0,39 & $-0,01$ \\
\hline$x 6$ & 0,45 & 0,24 & 0,24 & $-0,19$ & 0,31 & 1,00 & 0,07 & 0,30 & $-0,04$ \\
\hline $\mathrm{X} 7$ & 0,24 & 0,33 & 0,10 & $-0,09$ & 0,23 & 0,32 & 1,00 & 0,00 & 0,02 \\
\hline $\mathrm{X} 8$ & 0,46 & 0,44 & 0,43 & $-0,18$ & 0,43 & 0,53 & 0,31 & 1,00 & 0,00 \\
\hline X9 & 0,12 & 0,00 & $-0,10$ & $-0,04$ & $-0,05$ & 0,08 & 0,07 & $-0,03$ & 1,00 \\
\hline
\end{tabular}

Pada tahun 2011, kejadian tersebut tidak berubah. Aksesibilitas Lahan (X1) masih menjadi kendala yang sangat serius, khususnya yang berhubungan dengan X4 serta Kualitas Peraturan Daerah (X9). X4 juga berkorelasi negatif secara signifikan dengan X6 (Pajak dan Retribusi Lokal serta Biaya Transaksi Lainnya). Kualitas Peraturan, Pajak, dan Pungutan daerah sepenuhnya diatur oleh pemerintah daerah sehingga langkah-langkah penyesuaian dapat dilakukan dengan segera. Hal ini mungkin saja berarti pemerintah daerah tidak begitu responsif dalam memahami masalah ekonomi yang terjadi di wilayahnya. 
Dua korelasi positif tertinggi adalah X3 dengan X5 dan X2 dengan X3 pada tahun 2007. Di tahun 2011, dua korelasi positif tertinggi adalah X3 dengan X5 dan X1 dengan X6. Fakta tersebut menyampaikan kepada kita bahwa Kemampuan dan Integritas Pejabat Pemerintah Daerah (X5) sangat berkaitan dengan Interaksi antara Pemerintah Daerah dengan Sektor Swasta (X3) serta Izin Usaha (X2). Aksesibilitas Lahan yang lebih luas cenderung meningkatkan penerimaan pajak dan pungutan daerah.

Korelasi yang besar tersebut menunjukkan kepada kita kemungkinan untuk menyimpulkan konsep-konsep tata kelola ini dengan variabel yang lebih sedikit. Selain itu, fakta satu subindeks - Layanan Pengembangan Usaha - anehnya berkorelasi negatif dengan empat subindeks lainnya. Sementara itu, korelasi positif yang kecil antar sub-indeks ini dikarenakan konsep tata kelola tersebut overlap dalam batas-batas tertentu (McCulloch dan Malesky, 2010).

Sejauh ini, kita telah membahas tentang tata kelola perekonomian daerah di Indonesia dalam kerangka statis komparatif. Apakah sebenarnya fenomena tata kelola perekonomian daerah di setiap regional seperti yang terjadi pada Tabel 2 hingga 5 di atas bersifat sementara atau tetap? Akankah terjadi sebuah perubahan mendasar pada tata kelola perekonomian daerah dalam menghadapi masalah perekonomian yang terjadi di setiap daerah? Bagian terakhir akan menjawab pertanyaan di atas dengan lebih tegas.

Untuk menjawab pertanyaan-pertanyaan tersebut, beberapa penyesuaian dilakukan. Hal ini dikarenakan kabupaten/kota disampel oleh KPPOD, pada tahun tertentu, tidak dapat digunakan lagi pada survei tahunan berikutnya. Karena alasan tersebut, daerah yang terpilih adalah kabupaten/kota yang disampel pada tahun 2007 dan disurvei pada tahun 2011. Dalam hal ini terdapat 62 kabupaten/kota yang terpilih. Kemudian saya mengelompokkannya menjadi empat kategori, (a) sangat baik (peringkat 1-10), (b) baik (peringkat 11-50), cukup (peringkat 51-100), dan (d) buruk (peringkat lebih dari 100). Pengelompokan tersebut dilaksanakan masing-masing untuk tahun 2007 dan 2011. Hasilnya disajikan pada Tabel 6 dibawah.

Pada Tabel 6, terdapat hanya tiga daerah (yang disorot pada Tabel 1, yaitu Blitar, Magetan, dan Probolinggo) yang menempati posisi teratas dari 1 sampai 10 (kondisi A) pada tahun 2007 atau 2011. Klasifikasi B terdiri dari 6 daerah dengan peringkat 11 sampai 50. Diagonal utama dari kiri atas ke kanan bawah, menunjukkan tingkat persistensi yang tinggi pada posisi relatif kabupaten/kota, menunjukkan perubahan yang tetap pada tata kelola perekonomian daerah. Hal ini bermakna tidak ada peningkatan signifikan pada peringkat di atas 50 persen (32 daerah) dari kabupaten/kota yang diamati.

Hanya satu daerah (Kota Probolinggo) yang langsung berubah dari kondisi B ke kategori A pada tahun2007. Perubahan positif lainnya terjadi untuk tiga daerah. Tiga daerah, pada tahun 2007, bergerak dari kodisi C ke kondisi B pada tahun 2011. Empat daerah yang sebenarnya berada di kategori D naik ke posisi C pada tahun 2011. Ternyata, ada enam daerah yang masih berada pada kelompok D pada tahun 2007 yang langsung naik ke kategori B pada tahun 2011. 


\begin{tabular}{|c|c|c|c|c|c|c|}
\hline \multicolumn{7}{|c|}{$\begin{array}{l}\text { Tabel } 6 . \\
\text { Pengamatan Matriks Frekuensi dan Transisi Total Indeks Tata Kelola Perekonomian Daerah } \\
\text { pada Kabupaten/Kota yang terpilih, 2007-2011 }\end{array}$} \\
\hline \multirow{2}{*}{ Tahun } & \multirow{2}{*}{ Kondisi } & \multicolumn{5}{|c|}{2011} \\
\hline & & A & B & C & D & Total \\
\hline \multirow{6}{*}{2007} & A & $3(0,5000)$ & $0(0,0000)$ & $3(0,5000)$ & $0(0,0000)$ & 6 \\
\hline & B & $1(0,0714)$ & $6(0,4286)$ & $2(0,1429)$ & $5(0,3571)$ & 14 \\
\hline & C & $0(0,0000)$ & $3(0,2000)$ & $7(0,4667)$ & $5(0,3333)$ & 15 \\
\hline & D & $0(0,0000)$ & $6(0,2222)$ & $4(0,1482)$ & $17(0,6296)$ & 27 \\
\hline & Total & 4 & 15 & 16 & 27 & 62 \\
\hline & Ergodic & 0,0233 & 0,1629 & 0,1454 & 0,2879 & \\
\hline
\end{tabular}

Hal ini berbeda dengan 15 daerah lain yang mengalami penurunan posisi. Contohnya, ada tiga daerah yang awalnya berada pada kondisi A di tahun 2007 turun bahkan hingga posisi C. Secara keseluruhan, tidak ada pergerakan langsung dari D ke A atau C ke A (atau sebaliknya) yang nampak - tidak ada perubahan tata kelola pada sampel ini - jadi tingkat pergerakan terbatas pada kategori yang lebih baik, sejalan dengan studi yang dilakukan oleh McCulloch dan Malesky.

Transisi tersebut diasumsikan terus berkembang melalui mekanisme rantai markov hingga tercapainya kondisi yang stabil.Baris terakhir pada Tabel 6 menyajikan probabilitas kejadian ergodic. Hasil perhitungan menunjukkan adanya peluang kecil (2.33 persen) pada jangka panjang bagi daerah-daerah tersebut untuk tetap berada pada 10 peringkat terbaik. Probabilitas untuk mencapai kategori B dan C relatif cukup rendah, masing-masing berkisar 16.29 dan 14.54 persen. Hal ini mengimplikasikan bahwa pemerintah daerah belum optimal dalam meningkatkan tata kelola perekonomian daerah, walaupun telah berada pada peringkat baik.

Probabilitas terbesar berada pada kelompok D (peringkat lebih dari 100). Probabilitas pada posisi D berkisar 28.79 persen. Persistensi tertinggi daerah pada kondisi terendah seharusnya, dan tentunya, menjadi perhatian utama para akademisi maupun pengambil kebijakan: atau mungkin saja ada semacam tata kelola buruk yang tak nampak. Hal ini terjadi karena kendala struktural sehingga daerah-daerah tersebut tidak bisa tumbuh secepat daerah lainnya. Maka dari itu, posisinya pun tetap tidak berubah. Jadi, agar tata kelola yang buruk tersebut bisa menjadi lebih baik, perlu adanya sentuhan kewirausahaan dari pemerintah untuk menyelesaikan masalah-masalah tertentu di setiap daerah.

Hasil saat ini sejalan dengan intuisi yang didapatkan dari inspeksi visual grafik di atas, karena polarisasi tidak diprediksi pada kabupaten/kota pada tahun 2007-2011, akan tetapi, beberapa titik tumpu berada di sekitar nilai rata-rata. Meskipun demikian, hasil ini mungkin saja menunjukkan semacam ekternalitas geografis, sejalan dengan Krugman (1991a, 1991 b). Spillovers antar daerah yang bersebelahan dapat mendorong peningkatan tata kelola pada 
wilayah yangdipengaruhinya. Khususnya saat mengkaji daerah-daerah dengan kondisi terbaik pada tahun 2007 dan 2011, pergerakan indeks tata kelola tertinggi yang berada di Indonesia bagian barat dapat diamati, seperti Jawa, Sumatera, dan Bali, sementara di periode yang sama, beberapa daerah yang cukup mampu berada di wilayah lainnya. Kesimpulannya adalah seluruh perangkat analisis yang digunakan pada makalah ini memberikan indikasi kuat bahwa tidak ada peningkatan yang begitu signifikan pada tata kelola perekonomian daerah khususnya kabupaten/kota di Indonesia.

\section{KESIMPULAN}

Makalah ini mencoba untuk mengamati tata kelola perekonomian daerah khususnya di kabupaten/kota di Indonesia melalui sejumlah pengukuran indeks tata kelola perekonomian. Pengamatan tahun 2007 dan 2011 menunjukkan tidak ada perubahan yang signifikan pada kinerja tata kelola perekonomian daerah. Tidak berubahnya kinerja tata kelola perekonomian daerah dikarenakan masalah lahan, program pengembangan usaha, pajak dan pungutan serta biaya transaksi lainnya, keamanan, dan peraturan daerah.

Hasil tersebut mengemukakan perlunya peningkatan tata kelola perekonomian daerah dengan menciptakan iklim investasi untuk mendorong pertumbuhan aktifitas ekonomi. Industri di beberapa daerah tertentu akan berkembang jika daerah tersebut memiliki iklim investasi yang baik. Terkait bagaimana meningkatkan iklim investasi, pemerintah daerah seharusnya fokus pada pembangunan ekonominya utamanya pembangunan infrastruktur yang baik di wilayah tersebut, khususnya aksesibilitas lahan dan program pengembangan usaha. Pemerintah pusat dapat mendorong beberapa kebijakan peningkatan infrastruktur nasional dan memberikan rangsangan bagi pemerintah daerah untuk memprioritaskan pengadaan infrastruktur.

Akhirnya, harus dicatat bahwa tata kelola perekonomian daerah merupakan syarat bagi pertumbuhan perekonomian daerah, tapi bukan merupakan kondisi yang cukup untuk peningkatan kinerja perekonomian daerah. Nampaknya tata kelola daerah dapat menjadi penjelas (gejala) dari pertumbuhan ekonomi daerah, dibandingkan penyebab kinerja perekonomian daerah. Hal ini juga sejalan dengan gagasan bahwa segala usaha untuk meningkatkan tata kelola daerah membutuhkan perhatian yang lebih besar untuk memahami bagaimana karakteristik struktural yang mengatur ekonomi politik daerah hingga pada akhirnya berpengaruh terhadap kinerja perekonomian yang sejalan dengan desentralisasi dan otonomi daerah.

Tata kelola perekonomian daerah khususnya di Indonesia masih terbuka dan relevan untuk dianalisa. Makalah ini hanya menggunakan dua poin data sampel. Penelusuran lebih jauh dapat dilakukan dengan menggunakan perangkat yang lebih canggih. Penggunaan data time series terbaru dan menerapkan, contohnya, metode rantai Markov untuk variabel yang kontinyu, sangat disarankan sehingga dinamika transisi tata kelola perekonomian daerah lebih akurat bagi pembuat kebijakan untuk menyelesaikan masalah terkait. 


\section{DAFTAR PUSTAKA}

Acemoglu D., S. Johnson, dan S. Robinson, (2005), "Institutions as the Fundamental Cause of Long-Run Growth" in P. Aghion and S. Durlauf, (Eds.), Handbook of Economic Growth, Volume 1, Part A, Elsevier: 385-472.

Alt, J.E. dan K.A. Shepsle, (Eds.), (1990), Perspectives on Positive Political Economy, Cambridge: Cambridge University Press.

Amemiya, T., (1985), Advanced Econometrics, Basil Blackwell, Oxford.

Ardagna, S., danA. Lusardi, (2008), "Explaining International Differences in Entrepreneurship: The Role of Individual Characteristics and Regulatory Constraints", NBER Working Paper Series, No. 14012, May.

Banerjee, A. dan L. Iyer, (2005), "History, Institutions, and Economic Performance: the Legacy of Colonial Land Tenure Systems in India", American Economic Review, 95(4), 1190-213.

Bardhan, P., (1984), The Political Economy of Development in India. Oxford: Basil Blackwell.

Bates, R.H., (2001), Prosperity and Violence: The Political Economy of Development, New York: W.W. Norton.

Bhagwati, J.N., (1982), "Directly Unproductive, Profit-Seeking (DUP) Activities", Journal of Political Economy, 90(5): 988-1002.

Cali, M., (2009), "Do Effective State Business Relations Matter for Economic Growth? Evidence from Indian States", Manchester, Research Program Consortium for Improving Institutions for Pro-Poor Growth (IPPG).

Chibba, M., (2009), "Governance and Development, the Current Role of Theory, Policy and Practice", World Economics, Vol. 10, No. 2, April-June 2009: 78-108.

Colander, D.C. (Ed.), (1984), Neoclassical Political Economy: The Analysis of Rent-Seeking and DUP Activities, Cambridge Massachusetts: Ballinger Publishing Co.

Djankov, S., R. Porta, F. Silanes. dan A. Shleifer, (2002), "The Regulation of Entry", Quarterly Journal of Economics, 117: 1-37.

Di Tella, R. dan E. Schargrodsky, (2003), "The Role of Wages and Auditing during a Crackdown on Corruption in the City of Buenos Aires", Journal of Law and Economics,46: 269-92. 
Di Tella, R., S. Galiani, dan E. Schargrodsky, (2007), "The Formation of Beliefs: Evidence from the Allocation of Land Titles to Squatters", The Quarterly Journal of Economics, Vol. 122, No. 1.

Dixit, A.K., (2001), "On Modes of Economic Governance", CESifo Working Paper Series No. 589.

Field, E., (2007), "Entitled to Work: Urban Tenure Security and Labor Supply in Peru", The Quarterly Journal of Economics, Vol. 122, No. 4 (November): 1561-602.

Fisman, R., (2001), "Estimating the Value of Political Connections", American Economic Review, 91(4): 1095-102.

Galiani, S. dan E. Schargrodsky, (2010), "Property Rights for the Poor: Effects of Land Titling, Journal of Public Economics,94: 700-29.

Golden, M. dan L. Picci, (2005), "Proposal for a New Measure of Corruption, Illustrated with Italian Data", Economics and Politics, 17: 37-75.

Hariyoga, H., (2009), "The Determining Factors of Local Economic Performance, Challenges, and Obstacles", paper presented in the Focus Group Discussion in the Coordinating Ministry of Economy", Jakarta, November 12.

Helpman, E., (2008), Institutions and Economic Performance, Cambridge, Harvard University Press.

Istiandari R., (2009), "Local Economic Governance and Social Welfare in Indonesia", KPPOD Brief, May-June.

Kaufmann, D., A. Kraay, danP. Zoido-Lobatón, (1999), "Governance Matters", World Bank Policy Working Paper No. 2196. World Bank: Washington.

Kaufmann, D., A. Kraay, danP. Zoido-Lobaton, (2000), "Governance Matters: From Measurement to Action", Finance and Development, 37(2), Washington DC: International Monetary Fund.

Kaufmann, D., A. Kraay, danM. Mastruzzi, (2005), Governance Matters IV: Governance Indicators for 1996-2004, World Bank Policy Research Working Paper.

Knack, S. danP. Keefer, (1995), "Institutions and Economic Performance: Cross-Country Tests Using Alternative Institutional Measures", Economics and Politics,7(3): 207-27.

Knack, S. danP. Keefer, (1997), "Why Don't Poor Countries Catch Up?, A Cross-National Test of an Institutional Explanation", Economic Inquiry,35(3): 590-602.

Knack, S., (Ed.), (2003), Democracy, Governance, and Growth, Ann Arbor: The University of Michigan Press. 
Kong, T., (2011), "Governance Quality and Economic Growth", College of Business and Economics, Australian National University Working Paper No: 537, January.

KPPOD, (2011), KPPOD Brief, January- March 2011.

Krueger, A.O., (1974), "The Political Economy of the Rent-Seeking Society", American Economic Review,64(3): 291-303.

Krugman, P., (1991a), "Increasing Returns and Economic Geography", Journal of Political Economy, 99(3): 483-99.

Krugman, P., (1991b), Geography and Trade, MIT Press, Cambridge.

Kuncoro, H., (2005), "The Impact of Intergovernmental Transfer on Fiscal Performance, Economic Growth, and Regional Disparity in Indonesia", Unpublished Dissertation, Universitas Gadjah Mada, Yogyakarta.

Kuncoro, H. and Suryanto, (2003), "Regional Economic Growth Dynamics in Indonesia", The Journal of Accounting, Management, and Economics Research, Faculty of Economics UTY, Yogyakarta, Vol. 3, No. 2, September: 169-85.

Laeven, L., and C. Woodruff, (2007), "The Quality of the Legal System, Firm Ownership, and Firm Size", Review of Economics and Statistics,89.4: 601-14.

Lal, D. and H. Myint, (1996), The Political Economy of Poverty, Equity, and Growth: A Comparative Study, Oxford: Clarendon Press.

Lewis, B., (2003), "Tax and Charge Creation by Regional Governments under Fiscal Decentralisation: Estimates and Explanations", Bulletin of Indonesian Economic Studies, $39(2)$.

Lucas, R., (1988), "On the Mechanics of Economic Development", Journal of Monetary Economics, 22: 3-42.

Mahi, B.R., (2009), "Geographical Concentration of Industries: The Impact of Governance and Investment Climate in Region", paper presented in the Focus Group Discussion in the Coordinating Ministry of Economy", Jakarta, November 12.

Malesky, E. dan K. Samphantharak, (2008), "Predictable Corruption and Investment Strategy: Evidence from a Natural Experiment and Survey of Cambodian Entrepreneurs", Quarterly Journal of Political Science 3, 3: 227-67.

Malesky, E. dan M. Taussig, (2009), "Out of the Gray: The Impact of Provincial Institutions on Business Formalization in Vietnam", Journal of East Asian Studies, 9: 249-90.

McCulloch, N. dan E. Malesky, (2010), "Does Better Local Government Governance Induce Local Economic Growth Performance in Indonesia?", working paper, KPPOD, Institute of Development Studies, and AusAid. 
Mengistu, A.A. dan B.K. Adhikary, (2011), "Does Good Governance Matter for FDI Inflows? Evidence from Asian Economies", Asia Pacific Business Review, Volume 17, Issue 3: 281-99. North, D.C., (1981), Structure and Change in Economic History, New York, W.W. Norton.

North, D.C., (1990), Institutions, Institutional Change, and Economic Performance, Cambridge University Press, UK.

Olken, B.A., (2007), "Monitoring Corruption: Evidence from a Field Experiment in Indonesia", Journal of Political Economy, 115, (2): 200-49.

Pambudhi, A., (2009), "Government Governance and Economic Growth", paper presented in the Focus Group Discussion in the Coordinating Ministry of Economy", Jakarta, November 12.

Pepinsky, T.C. dan M.M. Wihardja, (2009), "Decentralization and Economic Performance in Indonesia", Paper presented at the 2009 Annual Meeting of the American Political Science Association. Chicago.

Posner, R.A., (1975), "The Social Costs of Monopoly and Regulation", Journal of Political Economy, 83(4): 807-27.

Quibria, M.G., (2006), "Does Governance Matter? Yes, No, or Maybe: Some Evidence from Developing Asia", Kyklos, 59(1): 99-114.

Romer, P., (1986), "Increasing Returns and Long Run Growth", Journal of Political Economy, 94: $1002-37$.

Romer, P., (1990), "Endogenous Technological Change", Journal of Political Economy, 98: S71S102.

Romer, D., (1996), Advanced Macroeconomics, McGraw-Hill Co., Inc., New York.

Sebayang, D. dan H. Kuncoro, (2011), "The Role of Business Development Service in Development Small Medium Enterprise Center in Order to Build a Regional Economic Partnership", paper presented in the International Conference "Political Economy of Trade Liberalization in East Asia", Faculty of Economics and Business, Universitas Brawijaya, Malang, November, 2425.

Silverman, B.W., (1986), Density Estimation for Statistics and Data Analysis, Chapman and Hall, New York.

Thomas, M.A., (2007), "What Do the Worldwide Governance Indicators Measure?", European Journal of Development Research, 22 (1): 31-54.

Wei, S.J., (2000), "Local Corruption and Global Capital Flows", Brookings Papers on Economic Activity (2): 303-54. 
Weiss, T.G., (2005), "Governance, Good Governance, and Global Governance: Conceptual and Actual Challenges," in R. Wilkinson, (Ed.), the Global Governance Reader, New York: Routledge.

Williamson, O., (1975), Markets and Hierarchies, Analysis and Antitrust Implications: A Study in the Economics of Internal Organization, New York: Free Press.

Williamson, O., (1985), The Economic Institutions of Capitalism: Firms, Markets, and Relational Contracting, New York: Free Press.

World Bank, (2005), Governance Indicators: 1996-2004,Washington DC: World Bank. 
Halaman ini sengaja dikosongkan 